\begin{tabular}{|l|l|l||}
\hline \multicolumn{2}{|c|}{ PublisherInfo } \\
\hline \hline PublisherName & $:$ & BioMed Central \\
\hline \hline PublisherLocation & $:$ & London \\
\hline \hline PublisherImprintName & $:$ & BioMed Central \\
\hline \hline
\end{tabular}

\title{
Discovering the secrets of Hsp90 binding
}

\begin{tabular}{|l|l|l||}
\hline \multicolumn{2}{|c|}{ ArticleInfo } \\
\hline \hline ArticleID & $:$ & 4844 \\
\hline \hline ArticleDOI & $:$ & $10.1186 /$ gb-spotlight-20030925-01 \\
\hline \hline ArticleCitationID & $:$ & spotlight-20030925-01 \\
\hline \hline ArticleSequenceNumber & $:$ & 196 \\
\hline \hline ArticleCategory & $:$ & Research news \\
\hline ArticleFirstPage & $:$ & 1 \\
\hline \hline ArticleLastPage & $:$ & 3 \\
\hline \hline & & RegistrationDate : 2003-9-25 \\
\hline ArticleHistory & $:$ & OnlineDate \\
\hline \hline ArticleCopyright & $:$ & BioMed Central Ltd2003-9-25 \\
\hline \hline ArticleGrants & $:$ & \\
\hline \hline ArticleContext & $:$ & 130594411 \\
\hline \hline
\end{tabular}




\section{David Secko}

Email: dmsecko@interchange.ubc.ca

Geldanamycin is an antibiotic that binds to Hsp90 and inhibits its adenosine triphosphate binding and activity as a chaperone. A derivative of geldanamycin (GM) is the Hsp90 inhibitor 17-allylaminogeldanamycin (17-AAG), which preferentially kills tumor cells and is in phase I clinical trials. Hsp90 is found in all cell types, but it has been unclear how the preferential killing of tumor cells by 17-AAG is accomplished. In the September 25 Nature, Adeela Kamal and colleagues at Conforma Therapeutics Corporation report that Hsp90 from tumor cells binds with higher affinity to 17-AAG and that this is due to Hsp90 being in multichaperone complexes in these cells. (Nature, 425:407-410, September 25, 2003)

Kamal et al. performed competitive binding assays using increasing concentrations of 17-AAG to inhibit the binding of Hsp90 to GM-biotin and observed that Hsp90 from tumor cells had a 50\% inhibitory concentration (IC 50) of $6 \mathrm{nM}$ compared with 400-600 nM for Hsp90 from control cells. Measurements comparing the binding of adenosine triphosphate (ATP) to Hsp90 also showed a lower IC 50 for tumor Hsp90, revealing that Hsp90 in tumor cells had a significantly higher binding affinity for 17-AAG. Hsp90 assembles in multichaperone complexes by interacting with many cochaperone proteins (e.g., p23, Hop), and co-immunoprecipitation of Hsp90 demonstrated that Hsp90 from tumor cells is present in more of these complexes. Hsp90 tumor complexes also showed a higher ATPase activity (something that Hsp90 chaperone function is dependent on) that was inhibited by 17-AAG. In addition, in vitro reconstituted Hsp90 complexes showed an increased apparent affinity for 17-AAG-12 nM for Hsp90 alone rising to $600 \mathrm{nM}$ when complexed. The authors then performed these experiments in mice and in clinical cancer and observed a similar pattern of 17-AAG binding to in vivo tumor Hsp90.

"Our data show that Hsp90 in tumor cells exists in a functionally distinct molecular form. [Hsp90 could be the] Achilles heel of tumor cells, driving the selective accumulation and bioactivity of pharmacological Hsp90 inhibitors, and making tumor Hsp90 a unique cancer target," conclude the authors.

\section{References}

1. Heat shock protein 90 as a molecular target for cancer therapeutics

2. Nature, [http://www.nature.com/nature/] 
3. Conforma Therapeutics, [http://www.conformacorp.com/corporate.htm]

4. Hsp90: chaperoning signal transduction

This PDF file was created after publication. 